\title{
Facts or Quests: The Controversy Around the Facts of Melville’s Stay in Marquesas
}

\author{
LIANG Ying \\ Beijing Foreign Studies University, Beijing, China
}

\begin{abstract}
Herman Melville's Typee (1846) is a fictionalized account of Melville’s sojourn in the Marquesas Islands. The book was originally published as an authentic travel narrative and Melville claimed the literal truth of the facts. Although Typee was an immediate success, it stirred up a noisy controversy about Melville's veracity. This article argues that Typee is something between fiction and autobiography, romance and travel book. Today when literary categories are breaking down, we know that the point is not to choose between one another; but instead, to discover how the fact and fiction cohere or coincide.
\end{abstract}

Keywords: fact, fiction, romance, travel

Herman Melville’s first book Typee: A Peep at Polynesian Life (1846) "enjoyed remarkable success" when published, and gave Melville "a celebrity of sorts" (Adamson, 1997, p. 18). It is a "fictionalized account" (Adamson, 1997, p. 18) of Melville's four-week sojourn in the Marquesas Islands and it describes the idyllic lives of the South Sea natives. "A story of a man's life among cannibals in a romantic and escapist setting” (Mason, 1972, p. 37) appears in an age "charmed by exotic accounts of natives" (Miller, 1975, p. 120) among "city-dwellers thirsty for action” (Mason, 1972, p. 37)—is a remarkable thing. No wonder its success was “instantaneous and spectacular” (Rosenberry, 1979, p. 25).

On January 3, 1841, at the age of twenty-two, Herman Melville shipped as a common seaman on the Acushnet of Fairhaven, a whaler sailing from New Bedford. Eighteen months later the vessel lay at anchor in the harbor of Nukuheva. Chafing at the dull routine and harsh conditions of shipboard life, lured by the lush green of an island paradise, Melville, along with companion Richard Tobias Green, the “Toby” of the novel, deserted. (Grejda, 1974, p. 13)

The natives of the Marquesas Islands "are among the most primitive of the Polynesians” (Grejda, 1974, p. 13). Melville observes "their appearance, their character, their relative merits and defects in comparison to the white man” (Grejda, 1974, p. 13) and his "peep” forms the raw material for the book Typee. The book was “originally published as an 'authentic' [or autobiographical] travel narrative” (Colatrella, 2002, p. 91) and Melville claimed the literal truth of the facts as he presented them in the book. Critics also have observed many parallels between Melville and Tommo (the first person narrator), including the notorious leg problem Melville developed while he was in the Marquesas and the mysterious leg wound Tommo suffers while hiding out after jumping ship and escaping to the interior of the island (Tolchin, 1988, p. 26).

LIANG Ying, Ph.D., Associate Professor, Graduate School of Translation and Interpretation, Beijing Foreign Studies University. 
"Although Typee was an immediate success, it stirred up a noisy controversy about Melville's 'veracity”" (Herbert, 1980, p. 181). Readers' skepticism is suspended between fact and fiction (Rosenberry, 1979, p. 25) because they "doubted that 'Herman Melville' was a real person, and that his account of his experience in the Marquesas Islands was true” (Renker, 1996, p. 1). Frederick Saunders later recalled that "a substantial if not wholly completed manuscript” was "formally submitted to him [Saunders] as a reader for the House of Harper”, but it was rejected, "on the grounds that "it was impossible that it could be true and therefore was without real value”" (Howard, 1968, p. 278). "British readers in particular were incredulous that any common sailor could write so well” (Renker, 1996, p. 1). "There is a story that the book was published in London only on Melville's specific guarantee that everything in it was true” (Mason, 1972, p. 23).

Melville has "a discouraging fear that his own promising career might be cut short by the growing opinion that he was a romancer rather than a historian of his own experiences" (Howard, 1951, p. 100). He was "sufficiently disturbed” that he prepared "an anonymous article” (Howard, 1951, p. 99) in its defense and sent it for possible publication. But the problem of veracity was providently solved. Toby miraculously comes back "in time to vouch for the veracity of his old shipmate's yarn life among the cannibals” (Rosenberry, 1979, p. 25), thereby "refuting those critics who had questioned its veracity; and (in the case of the British critics) the fact that Typee had been written by a common sailor" (Pullin, 1978, p. 26). It is not known whether Toby learned of the controversy back home in Buffalo, N. Y., and came over on his own accord or at Melville or a related party's request, but "armed with Toby's testimonial and supplementary information about his part in the escape from Typee, Melville was not only to muffle his critics but to write a formal 'Sequel' to his tale as an added attraction to subsequent editions” (Rosenberry, 1979, p. 37).

Yet Melville still realistically adapts himself "to the genteel standards of publishers interested in gaining the largest possible audience” (Miller, 1975, p. 119) and makes quite some corrections on the original manuscript. Murray "insisted on Melville’s adding more factual material about life on the island to increase the authenticity" (Pullin, 1978, p. 8) or to "substantiate the truth of the narrative somehow" (Renker, 1996, p. 1). Melville "bent over" (Miller, 1975, p. 119), “even though he knew, or should have known, that the insertion of factual material about the Polynesian natives marred the story line” (Miller, 1975, p. 119). Melville ended up quadrupling

the book's length in order to justify the inclusion of scenes and incidents which may have been vaguely a part of his historical considerations but which he could describe in necessary detail only after research into the observations of others. (Howard, 1951, p. 94)

He also includes “in the revised American edition, in July 1846, of 'The Story of Toby, A sequel to Typee', which records the reappearance” (Miller, 1975, p. 121) of Toby. Especially after Toby confirmed the accuracy of the events recorded in Typee, this addition "may have silenced those who considered the book a romance rather than a true story" (Miller, 1975, p. 121).

The exaggeration in the book was also disturbing to its publishers. Therefore "the book's appearance among the more purely factual narratives in Murray's 'Colonial and Home Library"” forced Melville to “change its tone” to one "deliberately prosaic" (Mason, 1972, p. 41), though Parker makes a good observation that "As Tommo becomes more acclimatized to this society, so the factual element of the narrative becomes 
more prevalent” (1978, p. 19). Murray originally also refused to "risk so racy a title as Typee" (Rosenberry, 1979, p. 36) in his travel series. And yet Murray was amenable to Melville’s wishes and brought out the book under the ponderously prosaic titles.

The American title was Typee: A Peep at Polynesian Life. During a Four Months' Residences in a Valley of the Marquesas. The main title, Typee, is the one Melville favored. The English variant [because there were an American edition and an English edition], Narrative of a Four Months' Residence Among the Natives of a Valley of the Marquesas Islands; or, A Peep at Polynesian Life reflected John Murray's fear for the book’s accuracy as an authentic travel story and his desire to make it seem as pedestrian as other travelogs in his series. (Howard, 1968, p. 284)

The controversy around the book was also generated by the "indignation of missionary societies" (Rosenberry, 1979, p. 25). And actually "the issue in the United States was less the veracity than the dubious morality of the author's life among the 'savages' and his shocking disregard of the sensibilities of the American Christian missions” (Rosenberry, 1979, p. 36). "Indeed the angry response of many readers indicated that Melville had indeed struck at something actual” (Martin, 1986, p. 20). The publishers wish "that the book edify as well as entertain its readers" (Colatrella, 2002, p. 91).

Conventionally romance is "a rendering of experience that is emancipated from ordinary restraints" (Thompson, 1999, p. 68). But Melville’s romances intersect with the important philosophical and sociopolitical currents of the time and he refuses to "accept the public demand that romance be kept free of ethical and philosophical probings” (Herbert, 1980, pp. 189-190). In Typee, he presents social and cultural criticism “about cross-cultural interaction, colonialism” (Colatrella, 2002, p. 87), sexuality, class relations, the destructive effects of commerce and missionary forces, and the fact that savagery and civilization being complementary to each other, etc.-all these are under the guise of scientific reporting of a far away and exotic place. So "the claim of authenticity permitted Melville to demonstrate" his social critique. He also inserts "in the first edition of an Appendix relating differences in colonial attitudes of the English and French in the 1840s” (Miller, 1975, p. 121) and gives a final diatribe against the missionaries of the Sandwich Islands.

Later on Melville edited Typee and removed his attempts to "represent the atrocities committed by white colonizers and missionaries in the name of 'civilizing' the Marquesas Islands” (Powell, 2000, p. 5). In the summer of 1851, while working on the final revision of Moby-Dick, Melville wrote a letter to Hawthorne. In the letter he reveals his deeply conflicted feelings about his desire to "boldly declare ... [the] Truth" but on the other hand, his painful awareness that to do so is "ludicrous"- - "Try to get a living by the Truth—and go to the Soup Societies” (Melville, 1993, p. 190).

Actually the work was vehemently attacked by religious journals in Britain, but Melville seems to have been less sensitive to this than he was to the charges of romancing. The monumental work of Charles R. Anderson, Melville in the South Seas, was able to show that Melville deliberately altered many of the facts of his own experience precisely because readers expected a claim to be made for the work as fiction. "Anderson demonstrated" that Typee converts "Melville's 'relatively slight contact with primitive life' during a four-week sojourn in the Marquesas into Tommo’s extensive interaction during a four-month captivity” (Renker, 1996, p. 2). Yet, Melville was able to "extract from his experiences enough of a yarn to integrate the factual materials" (Miller, 1975, p. 120) and tell the tale through artifices of fiction. Melville writes from The Confidence Man that "while to all fiction is allowed some play of invention, yet, fiction based on fact should never be 
contradictory to it” (1964, p. 75). Typee is such kind of a factual narrative.

Wardsworth and Coleridge's manifesto in 1798 proclaims that poetry is "a spontaneous overflowing of emotions, the memories of which recollected in tranquility". Melville consistently implied that he wrote up his account from personal memories of genuine experiences. Miller observed that "the point of view [of the book] is that of the older Melville recalling the young Herman” (1975, p. 115). But what if Melville doesn’t have congenial material to work with, or he fails to recall and flesh out his adventures? One assistance he can get is his imagination. But he can also draw on "the imaginations and reminiscences of other writers" "where it suits him" (Mason, 1972, p. 23). Critics have corroborated, though Melville denies, that he blends "semiautobiographical accounts of his adventures in the South Seas with commentary developed from careful reading of other published travel narratives” (Colatrella, 2002, p. 87).

The interesting thing is that he did not acknowledge this way of securing the knowledge. One explanation he actually gives in the preface is that he wants to avoid the pretensions to philosophical research which was then characteristic of serious "writers of travels among barbarous communities" (Melville, 1968, p. xiii). Another possibility is that there is a general distinction between originality and using source books that is being established at the time. For instance, Parker remarked: “Typee was, after all, original-the first eyewitness account of Polynesian life with the readability of fiction—although he had unoriginally cannibalized his source —books and employed a second or third hand style" (1978, p. 184). "Melville seems to remember the whole time that he is specifically engaged upon a romance" (Mason, 1972, p. 41) and a romance is supposed to be inspired instead of conventional or derivative. Herbert also noticed that "the revisions of Typee had the effect of rendering the work more 'romantic' in the sense of detaching it from weighty ethical and philosophical concerns” (1980, p. 189).

So Typee is "something between fiction and autobiography" (Howard, 1951, p. 97), romance and travel book. Today "when literary categories are breaking down" (Pullin, 1978, p. 26), we know that the point is not to choose between one another; but instead, to discover how the fact and fiction cohere/coincide. This is particularly important for a work like Typee which mixes "the factual and the fiction in wildly experimental ways" (Colatrella, 2002, p. 87).

The portrait of the fabulous Fayaway is a typical example for this analysis. On one hand, Melville inserts “a romantic interlude” (Miller, 1975, p. 130). Fayaway conjures an erotic fancy, but “Tommo's worship of Fayaway's seductive beauty is grounded in a romantic bias—-he is a 'declared admirer'” (Grejda, 1974, p. 17). In fact, Fayaway is “implausible”, ethereal, and “unreal as a character” (Miller, 1975, p. 117).

It is generally believed that Fayaway is Melville's famous creation, yet she is only conventionally beautiful. And her beauty is not only a projection of a "male fantasy" (Person, 1988, p. 57) but also a white man's fantasy. Is this Tommo's projection of her or Melville's, because the author and narrator getting “conflated” is always a problem first-person point of view poses (Grejda, 1974, p. 13)? But if this is Tommo's, is Melville satirizing a white male's fantasy or is he representing a reality that we are all somehow conditioned by the society we live in? Some critics see her as a cream-puff out of sentimental novels transferred to an exotic setting. And if we compare Melville's treatment between the missionary's wife, the native Queen and Fayaway, Fayaway "represents no opposition of appearance and reality. Her character has not been obscured by any artificial form, precisely because she is perceived through a pure medium of desire” (Person, 1988, p. 58). 
"The fusion of fact and meaning in Melville's treatment" "does not occur in isolated critical incidents or moments of ecstasy” (Herbert, 1980, p. 179). He is “a conscious artist” (Mason 1972, p. 23). Does the adding of appendixes and sequels convince today’s readers? Is Typee "artistically" "strengthened by insertions” (Miller, 1975, p. 121)? Typee "was a substantially embellished version of the 'facts"” (Renker, 1996, p. 2), then can “Typee's inaccuracies” thus confirm "its nature as a work of art” (Martin, 1986, p. 17)? Does his borrowing from readings of history and anthropology embroider the story Typee or make it more "informative and plausible" (Howard, 1951, p. 97)? Can we say Typee draws the reader along its loose thread of narrative by the power of charm alone?

Typee defies easy distinctions and easy answers as well. Is Typee a novel, a romance, or travel book? Is it autobiography or anthropology (Pullin, 1978, p. 26)? Most of his contemporary critics believe that a large part of the book is based on Melville's own experiences. Here are two examples: "In a familiar way, he has merely described what he has seen" (qtd. in Rosenberry, 1979, p. 42); "some things he stretched, but mainly he told the truth” (qtd. in Rosenberry, 1979, p. 36). Generally,

in the $19^{\text {th }}$ century Melville's works, particularly Typee and Omoo, were regarded as essentially factual accounts of real journeys. Typee remained in print precisely because of its presumed value as an accurate account of observations made on a real journey. It was cited in professional studies of ethnology and comparative religion, by authorities as eminent as Sir James Frazer and J. J. Bachofen. With the revival of interest in Melville in the early $20^{\text {th }}$ century, it became possible to view Typee as a work of fiction, an apprentice work perhaps, but one nonetheless that bore certain relationships to Melville's by then more celebrated works, such as Moby-Dick, which were clearly viewed as fiction and not as fact. (Martin, 1986, p. 17)

Melville claimed that: "a real romancer of mine... is made of different stuff altogether" (Brodhead, 1978, p. 31). What he meant was referring to a kind of "new romance" which "was specifically outlined as a blend hybrid narrative that intermingled the actual and the imaginary" (Thompson, 1999, p. 104). Today, it is easier to reassess Melville's achievement in Typee. "Mixing the factual and the fiction in wildly experimental ways" (Colatrella, 2002, p. 87), Typee "inhabits the formal area which is only now being investigated by critics—-that area where fact and fiction are so closely allied as to be indistinguishable” (Pullin, 1978, p. 1). Moreover, the thick surface of "facts" of Typee provides a basis for Melville's social criticism whereas its "fictions" enable Melville to make his own use of this material and to turn a literary narrative into an exposition on other levels. Here lies the area where Melville explores and redefines romance.

"Human society cannot exist without tension and conflict” (Pullin, 1978, p. 21). Even if we are supposed to be step by step closer to an age which breaks down all human boundaries, this critical controversy of the time "concerning the facts of Melville’s experience in the Marquesas" (Pullin, 1978, p. 8) is still worthy to be noted. We may be ahead of Melville's contemporaries in that we now accept the idea that romance has romantic, realistic, allegorical, and symbolic modes, etc., just like Typee, it can be "an effective fusion of all these modes" (Pullin, 1978, p. 26); and we also know that "any hard-and-fast separation between the novel and the romance did not have much point” (Thompson, 1999, p. 68). Yet still there are things that this incident has more to say to us. History repeats itself whenever it is forgotten.

\section{References}

Adamson, J. (1997). Melville, shame, and the evil eye: A psychoanalytic reading. New York: State University of New York Press. 
Brodhead, R. H. (1978). Mardi: Creating the creative. In F. Pullin (Ed.), New perspectives on Melville (pp. 29-53). Kent: The Kent State University Press.

Colatrella, C. (2002). Literature and moral reform: Melville and the discipline of reading. Gainesville: University Press of Florida.

Grejda, E. S. (1974). The common continent of men: Racial equality in the writings of Herman Melville. Port Washington: Kennikat Press.

Herbert, T. W. Jr. (1980). Marquesan encounters: Melville and the meaning of civilization. Cambridge: Harvard University Press.

Howard, L. (1951). Herman Melville: A biography. Berkeley: University of California Press.

Howard, L. (1968). Historical note. In H. Melville, Typee: A peep at Polynesian life. H. Hayford, (Ed.). Evanston and Chicago: Northwestern University Press and The Newberry Library.

Martin, R. K. (1986). Hero, captain, and stranger: Male friendship, social critique, and literary from in the sea novels of Herman Melville. Chapel Hill: The University of North Carolina Press.

Mason, R. (1972). The spirit above the dust. Mamaroneck, NY: Paul P. Appel Publisher.

Melville, H. (1964). The confidence-man. Signet Edition.

Melville, H. (1993). Correspondence. Chicago: Northwestern and Newberry Library.

Melville, H. (1968). Typee: A peep at Polynesian life. H. Hayford, (Ed.). Evanston and Chicago: Northwestern University Press and The Newberry Library.

Miller, E. H. (1975). Melville. New York: George Braziller.

Parker, H., \& Brian, H. (1978). The flawed grandeur of Melvile’s Pierre. In F. Pullin (Ed.), New perspectives on Melville (pp. 162-196). Kent: The Kent State University Press.

Person, L. S. Jr. (1988). Aesthetic headaches: Women and a masculine poetics in Poe, Melville, and Hawthorne. Athens: The University of Georgia Press.

Powell, T. B. (2000). Ruthless democracy: A multicultural interpretation of the American renaissance. Princeton, New Jersey: Princeton University Press.

Pullin, F. (1978). Melville’s Typee: The failure of Eden. In F. Pullin (Ed.), New perspectives on Melville (pp. 1-28). Kent: The Kent State University Press.

Renker, E. (1996). Strike through the mask: Herman Melville and the scene of writing. Baltimore: The Johns Hopkins University Press.

Rosenberry, E. H. (1979). Melville. London: Routledge \& Kegan Paul.

Thompson, G. R., \& Eric, C. L. (1999). Neutral ground: New traditionalism and the American romance controversy. Baton Rouge: Louisiana State University Press.

Tolchin, N. L. (1988). Mourning, gender, and creativity in the art of Herman Melville. New Haven: Yale University Press. 